\title{
JOB SATISFACTION STATUS OF PUBLIC PRIMARY SCHOOL TEACHERS: A CASE OF PAKISTAN ADMINISTRATIVE KASHMIR
}

\author{
Muhammad Shabbir, PhD Scholar \\ Prof. Dr. Song Wei, Executive Dean \\ Ghulam Nabi, PhD Scholar \\ Ahmed Nawaz Zaheer, PhD Scholar \\ Hamayo Khan, PhD Scholar
}

School of Public Affairs, University of Science and Technology of China,

Hefei, Anhui, P.R C

\begin{abstract}
This survey study was conducted to investigate the job satisfaction of Govt. primary school teachers in Pakistan administrative Kashmir. We applied Lester, P. E. (1987) teacher's job satisfaction questionnaire (TJSQ) with nine factors, supervision, colleague, working condition, pay, responsibility, working itself, advancement, security and recognition to assess the level of job satisfaction of primary school teachers. The sample consists of 150 government primary teachers from all over the Azad Jammu \& Kashmir. We applied descriptive statistics to analyze the data through IBM SPSS 21. The results show that primary teacher are satisfied by four factors (out of nine) of a job i.e. supervision, pay, responsibility, and advancement. Whereas for other five factor they responded moderate. The study recommends certain measures for the entire satisfaction of primary school teacher for better performance.
\end{abstract}

Keywords: Job Satisfaction, Primary School Teachers, Azad Jammu \& Kashmir

\section{Introduction}

Job satisfaction has been one of the most popular interests' among the researchers and practitioners from last few decades (Milda Astrauskaite, 2011; Rajendran, R , 2013). Study of job satisfaction has a long history, since 1919, job satisfaction has been broadly studied and discussed in the areas of organizational management \& behavior, industrial organization, social psychology, organizational personnel and human resource 
management, and (Cranny, C. J., Smith, P. C., \& Stone, E. F. 1992).The education system has also been changed into an organization. In the field of education, study of the job satisfaction of teachers has become a major focus of attention for researchers to make it a dynamic and competent ( M. Asgha Ali, 2011). People are at different in the amount to which they account job satisfaction, and the specifics for these differences lies in the nature of the jobs which different employees offer. Therefore, teacher job satisfaction refers to a teacher's relation to his or her teaching function and is a role of the perceived relationship between what one desires from teaching and what one perceives it is offering to a teacher, (Zembylas and Papanastasiou, 2004).

Primary education is fundamental stage of further education and job satisfaction of primary teachers is extremely important among all others categories of teachers because of importance of primary education which is basic stage of the pyramid of education system in the world. This necessitates the need to study and address the issue of primary school teachers' job satisfaction. A great level of research has been conducted in the developed countries to measure the job satisfaction of schools teachers (Linda Evans, 1997; Dmitri Van Maele and, Mieke Van Houtte, 2012; Ietje Veldman et al., 20013; Robert W. Lent et al., 2011, Robert M. Klassen, 2009). In developing countries such as in Pakistan few cases have been traced related to teacher's job satisfaction ( M. Asghar Ali, 2011; Nadim, 2012; Ghazi, S. R, 2012; Farah Deeba, 2013, M. Jamal Shah, 2012: Azhar M., 2011, Farida Shaikh, et al., 2012). However, there is a lack of studies that have investigated primary teachers' job satisfaction worldwide in general and in Pakistan or Pakistan administrative Kashmir. Especially AJ\&K until now I did not find any study related to area of job satisfaction so this is the first study of its kind in Azad Jammu \& Kashmir which is geopolitically very important part . This study attempts to explore the level of job satisfaction and dissatisfaction among Primary teachers and will provide evidence for those who directly involve in AJ\&K education system to analyze the current policies whether or not moving the institutions right direction toward achieving the national educational goals.

\section{Job satisfaction and dissatisfaction}

Commonly, job satisfaction is an effective response of employee's situation at work (E. C. Papanastasiou and M. Zembylas, 2005). Job satisfaction is an attitude, which results from balance, and abstract of several particular likes and dislikes practiced in connection with the job. This approach manifests itself in the assessment of job and employing organization. This evaluation may rest mostly upon one's success or failure in the attainment of individual objectives and upon the perceived contributions of the job and employing organization to these ends 
(Mahmood, Nudrat, \& Asdaque, 2011). In terms of definitions, generally there is no agreed upon description of teacher job satisfaction or of what constitutes teacher satisfaction although there might be some international trends such as, the perception that teachers are most satisfied by matters intrinsic to the role of teaching: student attainment, helping students, positive interaction with students and others, self growth and so on (Berg, 2002; Dinham \& Scott, 2002).

Newsroom, (1986) defined job satisfaction, as "It is a set of favorable or unfavorable feelings with which employees view their work."

Brayfield \& Rothe (1951) refers job satisfaction as the individual's attitude (feeling) toward his work. According to Hugh (1983), job satisfaction will be defined as "the amount of overall positive affect (of feeling) that individuals have towards their jobs".

Spector, (1956) defined job satisfaction as "how people feel about their jobs and different aspects of their jobs.”

Employers and employees both desire a more encouraging environment because of common interest, such as better performance and job satisfaction. Employers want better performance whereas employees feel that the climate is favorable when they are doing something useful that provides a sense of individual worth. They often want challenging work that is intrinsically satisfying. They want responsibility and the opportunity to succeed, to be listened to, treated and valued as individuals. They desire that the organizations should truly be concerned about their need and problem (Davis, 1985).

\section{Research on teacher's job satisfaction}

Teachers are arguably the most imperative group of professionals for all nations' future. Therefore, it is worrying to find that a lot of today's teachers are dissatisfied with their jobs. Concerning to study of Beer \& Beer (1992) who investigated the depression among Los Angeles teachers by applying depression scale the mean depression score of a sample of 75 teachers was 15.6. The CES-D score equal to 16 or greater is considered significant. According to Schonfeld, (1989) this level of depression score associated with risk of depression.

Teacher job satisfaction has remained as a large number of studies in many countries. Perhaps from last two decades, many studies have been conducted to identify sources of teacher satisfaction and dissatisfaction at elementary and secondary school level teachers.

Teacher's job satisfaction or dissatisfaction depends on a many factors ranging from where he teaches to the sense of self-fulfillment they may receive from doing teaching. Generally, job satisfaction involves a description of those factors that a teacher perceives to either promote 
positive feelings about job, or negative feelings about job (Ghazi, S. R, 2012). Imposed and centralized system accountability, lack of professional sovereignty, persistently obligatory changes, regular media criticism, lack of resources, and average salaries are major sources of low teacher satisfaction in many developed countries around the world (Dinham, S. and Scott, C. 2002; van den Berg, 2002).

Perpetual factors such as Student achievement, helping, student's positive relationships with colleagues and self growth have been associated with teacher job satisfaction, whereas further factors such as professed low status and pay, lack of professional independence and deprofessionalisation have been associated to teacher dissatisfaction, (Zembylas, M., \& Papanastasiou, E. ,2004).

Demographic factors and personal characteristics also associated with the job satisfaction. gender, age, qualification, years of teaching experience, subject, location, , responsibility, and activity are the such factors that influence on the teachers job satisfaction,(Aliakbari, 2013; Bishay,1996; Shujie Liu , Anthony J. Onwuegbuzie, 2012 ).

Satisfaction and dissatisfaction are also deeply correlated with performance of teachers. The satisfied teachers are known to show higher level work performance in teaching profession (Mbah, 2012; Alimi Baba Gana, 2011).Whereas dissatisfaction reduced aptitude to meet students' needs, major incidences of psychosomatic disorders leading to increase the trend of absenteeism, and high levels of claims for stress-related disability (Farber, 1991; Troman, 2000). Significantly, teacher dissatisfaction results to be a major motivation in teachers leaving the job in many countries (Woods et al.1997).

\section{Job Satisfaction of Primary Teachers: Case of Pakistan Administrative Kashmir}

Azad Jammu \& Kashmir remote area under Pakistan administration having area of 5134 square miles with 4.09 million population which came into existence as a result of civil war in 1947.( Malik 2002, Ajk govt). Pakistan administrative territory has educational administrative structure similar to Pakistan structure which was introduced by British government in subcontinent having the characteristics of too much centralization and authoritarianism with a series of reforms transformed gradually after independence brought through legislation without much thinking about the 'system', 'individual', and 'the organizational values' (Ghazi, S. R, 2012).

In Azad Jammu \& Kashmir educational fact and figure are better than other provinces of Pakistan but the primary schools have a poor infrastructure with lake of facilities. Although major portion of the budget (28\%) of the territory is being spend on education but still it is not sufficient 
to have good facilities for the teaching. Presently the educational data of AJK is that 4202 government primary school are established with 9589 available primary teachers and $41 \%$ are without buildings $87 \%$ without electricity, $73 \%$ are without availability of drinking water and $82 \%$ are without boundary walls (Pakistan Education Statistics, 2011). But according to the AJ\& K Planning and development department, which indicates different number of primary teachers, 8069 male and 6903 female total 14972 primary teachers employed in Azad Kashmir primary education department,( AJ\&K Planning and Development, 2014). This necessitates the need to investigate the teacher's job satisfaction in AJ\&K who working under the worse condition and poor infrastructure.

The researcher have an experience to work as a teacher both in public and private schools near about ten years and seen sometime conflicts rise between AJ\&K teacher union and Ministry of education. Usually in social media, sometime the government and common people; they criticize the public teacher's carelessness, laziness, purposeful lethargy, and lack of devotion, enthusiasm to work and absenteeism. On other hand the AJ\&K teacher's organization were disagreed by existing pay structure, benefits and working conditions do not satisfy their basic needs as much. But AJK governments and ministry of education have argued that the current economic realities in the state cannot prolong the demand in increasing of salaries, benefits, and urgently improvements in working conditions. Particularly they argue that teachers' demands are beyond the government resource.

The current situations demand to measure the job satisfaction, dissatisfaction of primary teachers in AJ\&K because teacher performance is closely related to job satisfaction and a better performance of a teacher can only be expected if they are satisfied with their jobs, ( R. Rajendran 2013; Alima Baba Gana, 2013).

\section{Significance of study}

The previous research indicates that satisfaction is highly correlated to performance of employees. More satisfied employees perform better and on other hand dissatisfied employees are more likely to resort to incapacitate and reflexive aggression resulted in not only turn down in organization performance but it creates negative attitude among employees and affect health too. Morally dissatisfaction creates negative attitude among employees affected in personal and social life and the stress that results from it, in fact increases one's susceptibility to mental diseases consequences in heart attacks. Satisfied employees build a satisfied society with psychologically healthy people hold positive attitudes toward life in general. 
In education sector primary education is fundamental stage provide a pillar for further high education so for it is very important that primary teachers should be satisfied with respect to all aspects of job satisfaction for sound education because health of primary schools depend upon the job satisfaction of primary teachers and it has been a significant concern to researchers and educationists in recent years. The current study is very scar in Pakistan and in AJ\&K I did not find any published research related to this area which is geographically very important territory.

\section{Objectives}

The current study intends to attain the following objectives:

- To explore the job satisfaction of primary school teachers in AJ\&K.

- To identify the deficiencies in this area and to provide the information to educational planners, administrators and policy makers for improvement of working situations in the schools and further studies to explore the problem in more depth.

\section{Research Methodology}

The population of this study mainly based on all primary teachers of Pakistan administrative Kashmir. A sample of total 150 teachers was selected randomly from three divisions Mirpur, Poonch and Muzafarabad.

Survey technique was applied to collect data through Lester, P. E. (1987), Development and factor analysis of the Teacher Job Satisfaction Questionnaire (TJSQ) with nine factors, Recognition, Security, Work itself, Responsibility, Working Condition, Advancement, Colleagues, Pay, and Supervision. This questionnaire is comprised of 66 items with five point likert scale format assessing nine facets of job satisfaction. Participants were asked to respond by scoring 1 to 5 , by representing whether they agree or disagree with each item on the scale. The overall job satisfaction score is computed by summing all 66 items. 50\% items were written in positive form and $50 \%$ items in negative form to minimize the response bias. Reverse scoring was necessary for items written in negative form which had been changed five into one and four into two.

We used descriptive statistics with help of software IBM SPSS 21 to analyze the data.

To measure the level of job satisfaction we applied Best's criteria (1977) that classified the level of job satisfaction into five categories which as follows: 


$$
\begin{gathered}
\frac{\text { High score }- \text { Lower score }}{\text { Number of levels }} \\
\frac{5-1}{5}
\end{gathered}
$$

$=0.80$

Table A The scale for understanding the means of level of satisfaction

\begin{tabular}{|l|l|}
\hline Mean score & Level of satisfaction \\
\hline $1.00-1.80$ & Very unsatisfied \\
\hline $1.81-2.60$ & Unsatisfied \\
\hline $2.61-3.40$ & Moderate \\
\hline $3.41-4.20$ & Satisfied \\
\hline $4.21-5.00$ & Very satisfied \\
\hline
\end{tabular}

\section{Findings}

\begin{tabular}{|l|l|l|l|l|l|l|}
\hline \multicolumn{2}{|c|}{ Table 1 Supervision factor } \\
\hline & $\begin{array}{l}\text { Number } \\
\text { of items }\end{array}$ & $\begin{array}{l}\text { Max. } \\
\text { Expected } \\
\text { Score }\end{array}$ & $\begin{array}{l}\text { Gained } \\
\text { score on } \\
\text { all items }\end{array}$ & $\begin{array}{l}\text { Mean } \\
\text { Score }\end{array}$ & $\begin{array}{l}\text { Standard } \\
\text { Deviation }\end{array}$ & Remarks \\
\hline 150 & 14 & 70 & 48.12 & 3.4371 & .27490 & Satisfied \\
\hline
\end{tabular}

The supervision factor consists of 14 items, related to Head master and assistant education officer's help, assistance, praise, relation with primary teacher and supervisory role. The expected score on these subscale items was 70 whereas gained score on these items is 48.12 . The means score and standard deviation of supervisory factor is 3.4371 and .27490 respectively. It is clear from that result that satisfaction toward the supervision factor is almost satisfied.

Table 2 Colleague factor

\begin{tabular}{|l|l|l|l|l|l|l|}
\hline $\mathbf{N}$ & $\begin{array}{l}\text { Number } \\
\text { of items }\end{array}$ & $\begin{array}{l}\text { Max. } \\
\text { Expected } \\
\text { Score }\end{array}$ & $\begin{array}{l}\text { Gained } \\
\text { score on } \\
\text { all items }\end{array}$ & $\begin{array}{l}\text { Mean } \\
\text { Score }\end{array}$ & $\begin{array}{l}\text { Standard } \\
\text { Deviation }\end{array}$ & Remarks \\
\hline 150 & 10 & 50 & 36.75 & 3.24 & .25508 & Moderate \\
\hline
\end{tabular}

The colleague factor consists of the 10 items. The respondents were asked questions related to their relation with colleagues/ co workers. The mean score on colleague factor is 3.24 whereas standard deviation is .25508 which indicates that teacher's satisfaction toward this factor is moderate. 
Table 3 Working condition factor

\begin{tabular}{|l|l|l|l|l|l|l|}
\hline $\mathbf{N}$ & $\begin{array}{l}\text { Number } \\
\text { of items }\end{array}$ & $\begin{array}{l}\text { Max. } \\
\text { Expected } \\
\text { Score }\end{array}$ & $\begin{array}{l}\text { Gained } \\
\text { score on } \\
\text { all items }\end{array}$ & $\begin{array}{l}\text { Mean } \\
\text { Score }\end{array}$ & $\begin{array}{l}\text { Standard } \\
\text { Deviation }\end{array}$ & Remarks \\
\hline 150 & 7 & 35 & 22.05 & 3.1495 & .69824 & Moderate \\
\hline
\end{tabular}

Working condition factor is combination of 7 items related to school physical condition, working condition and administrative policies. The mean score and standard deviation on working condition factor is 3.1495 and .69824 respectively. The mean score value indicates the teachers satisfaction toward school working condition is moderate.

Table 4 Pay factor

\begin{tabular}{|l|l|l|l|l|l|l|}
\hline $\mathbf{N}$ & $\begin{array}{l}\text { Number } \\
\text { of items }\end{array}$ & $\begin{array}{l}\text { Max. } \\
\text { Expected } \\
\text { Score }\end{array}$ & $\begin{array}{l}\text { Gained } \\
\text { score on } \\
\text { all items }\end{array}$ & $\begin{array}{l}\text { Mean } \\
\text { Score }\end{array}$ & $\begin{array}{l}\text { Standard } \\
\text { Deviation }\end{array}$ & Remarks \\
\hline 150 & 7 & 35 & 22.33 & 3.74 & .33115 & satisfied \\
\hline
\end{tabular}

Pay factor also consists of 7 items in which respondent were asked question related to their income and expenses, pay according to ability and pay comparison with similar jobs in other schools and provinces. The mean score on pay factor is 3.74 and standard deviation .33115. The mean score value indicates that teachers satisfaction toward pay is satisfied.

Table 5 Responsibility factor

\begin{tabular}{|l|l|l|l|l|l|l|}
\hline $\mathbf{N}$ & $\begin{array}{l}\text { Number } \\
\text { of items }\end{array}$ & $\begin{array}{l}\text { Max. } \\
\text { Expected } \\
\text { Score }\end{array}$ & $\begin{array}{l}\text { Gained } \\
\text { score on } \\
\text { all items }\end{array}$ & $\begin{array}{l}\text { Mean } \\
\text { Score }\end{array}$ & $\begin{array}{l}\text { Standard } \\
\text { Deviation }\end{array}$ & Remarks \\
\hline 150 & 8 & 40 & 31.73 & 3.9666 & .33931 & satisfied \\
\hline
\end{tabular}

Responsibility factor combines 8 items related to get along with students, awareness of school policies and teaching responsibility. The mean score this factor is 3.9666 and standard deviation .33931 which revealed that teacher satisfaction for responsibility factor is satisfied.

Table 6 working itself factor

\begin{tabular}{|l|l|l|l|l|l|l|}
\hline $\mathbf{N}$ & $\begin{array}{l}\text { Number } \\
\text { of items }\end{array}$ & $\begin{array}{l}\text { Max. } \\
\text { Expected } \\
\text { Score }\end{array}$ & $\begin{array}{l}\text { Gained } \\
\text { score on } \\
\text { all items }\end{array}$ & $\begin{array}{l}\text { Mean } \\
\text { Score }\end{array}$ & $\begin{array}{l}\text { Standard } \\
\text { Deviation }\end{array}$ & Remarks \\
\hline 150 & $\mathbf{9}$ & $\mathbf{4 5}$ & $\mathbf{3 0 . 6 4}$ & 3.4044 & .65522 & Moderate \\
\hline
\end{tabular}

Working itself subscale consist of nine items related to teachers interest to work, routine work, creativity, opportunity for variety of skills and freedom for own decision making. The mean score value for this subscale is 3.4044 with standard deviation .65522 which is evident that teacher's satisfaction for this factor is moderate. 
Table 7 Advancement factor

\begin{tabular}{|l|l|l|l|l|l|l|}
\hline $\mathbf{N}$ & $\begin{array}{l}\text { Number } \\
\text { of items }\end{array}$ & $\begin{array}{l}\text { Max. } \\
\text { Expected } \\
\text { Score }\end{array}$ & $\begin{array}{l}\text { Gained } \\
\text { score on } \\
\text { all items }\end{array}$ & $\begin{array}{l}\text { Mean } \\
\text { Score }\end{array}$ & $\begin{array}{l}\text { Standard } \\
\text { Deviation }\end{array}$ & Remarks \\
\hline 150 & 5 & 25 & 18.11 & 3.6227 & .49865 & satisfied \\
\hline
\end{tabular}

In table 7 advancement factor was measured. This facet of job satisfaction consists of 5 items related to teacher's opportunities for promotion. The mean score for this facet is 3.6227 with standard devotion .49865 which indicates that satisfaction for advancement factor is satisfied.

Table 8 Security factor

\begin{tabular}{|l|l|l|l|l|l|l|}
\hline $\mathbf{N}$ & $\begin{array}{l}\text { Number } \\
\text { of items }\end{array}$ & $\begin{array}{l}\text { Max. } \\
\text { Expected } \\
\text { Score }\end{array}$ & $\begin{array}{l}\text { Gained } \\
\text { score on } \\
\text { all items }\end{array}$ & $\begin{array}{l}\text { Mean } \\
\text { Score }\end{array}$ & $\begin{array}{l}\text { Standard } \\
\text { Deviation }\end{array}$ & Remarks \\
\hline 150 & $\mathbf{3}$ & 15 & $\mathbf{1 0 . 2 1}$ & $\mathbf{3 . 4 0 0 0}$ & .52519 & Moderate \\
\hline
\end{tabular}

In the security factor the respondents were asked for response for three items related to security of job. The mean score for this subscale is 3.4022 with standard deviation .52519. The mean value indicates that teachers level of satisfaction for this factor is moderate.

Table 9 Recognition factor

\begin{tabular}{|l|l|l|l|l|l|l|}
\hline $\mathbf{N}$ & $\begin{array}{l}\text { Number } \\
\text { of items }\end{array}$ & $\begin{array}{l}\text { Max. } \\
\text { Expected } \\
\text { Score }\end{array}$ & $\begin{array}{l}\text { Gained } \\
\text { score on } \\
\text { all items }\end{array}$ & $\begin{array}{l}\text { Mean } \\
\text { Score }\end{array}$ & $\begin{array}{l}\text { Standard } \\
\text { Deviation }\end{array}$ & Remarks \\
\hline 150 & $\mathbf{3}$ & $\mathbf{1 5}$ & $\mathbf{9 . 5 0 0 0 0}$ & 3.1667 & $\mathbf{0 . 7 5 9 4}$ & Moderate \\
\hline
\end{tabular}

The recognition factor consists of three items which explain the recognition of primary teachers in term of receiving recognition as good and successful teacher. The mean value for this factor is 3.1667 with standard deviation 0.7594 which indicates that teacher's satisfaction for this factor is moderate.

Table 10 Overall job satisfaction on all factors

\begin{tabular}{|l|l|l|l|l|l|l|}
\hline & N & Minimum & Maximum & Sum & Mean & $\begin{array}{l}\text { Std. } \\
\text { Deviation }\end{array}$ \\
\hline Valid N & 9 & 3.15 & 3.97 & 31.13 & 3.4588 & $\begin{array}{l}.27370 \\
\text { Satisfied }\end{array}$ \\
\hline
\end{tabular}

In table 10 overall job satisfactions for 9 factors were measured by summing and calculating the mean scores on all items. The overall job satisfaction for all factors is satisfied. 


\section{Graphical presentation of job satisfaction}

Figure 1

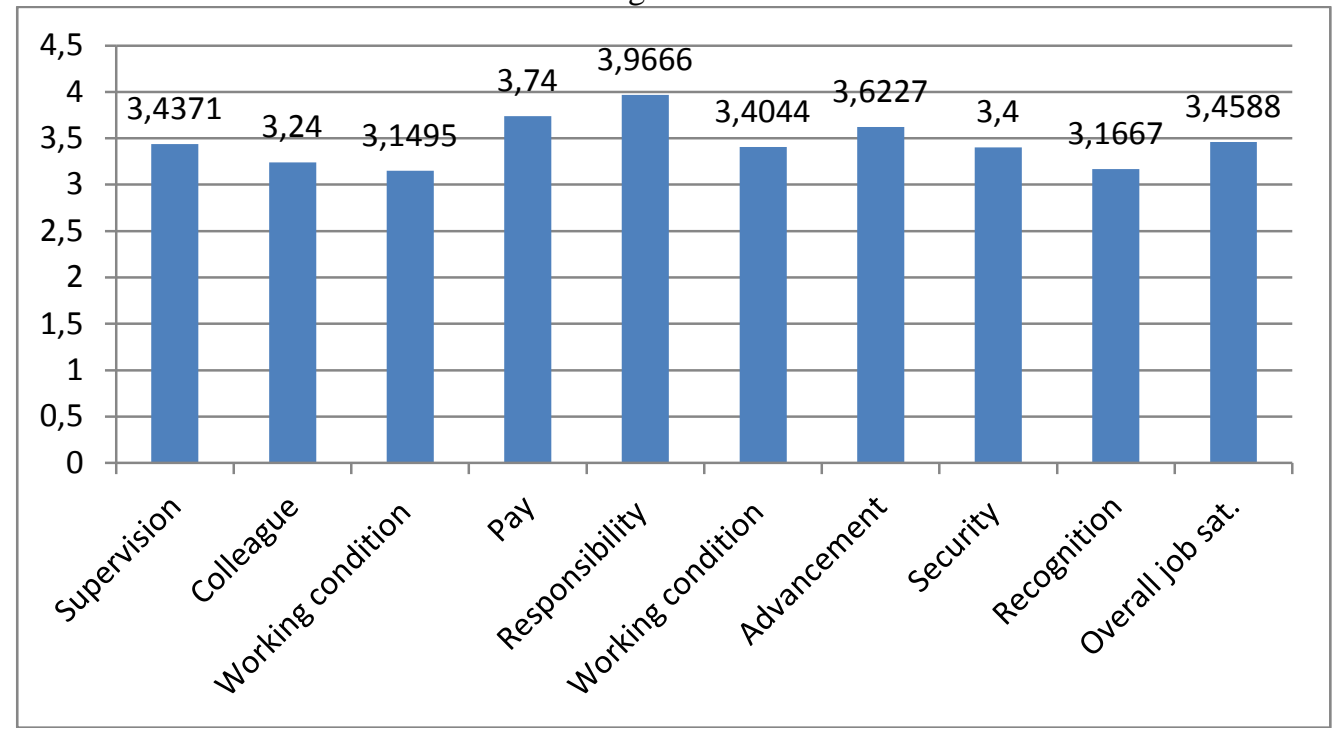

Figure 1 illustrates the levels of job satisfaction of respondent with nine factors including overall job satisfaction. The factors of job satisfaction are listed on the $\mathrm{X}$ axis and mean scores on the scale are indicated on the $\mathrm{Y}$ axis.

\section{Discussion}

The purpose of this study was to explore the level of job satisfaction of government primary teacher at Azad Jammu \& Kashmir. In education, the researcher have usually adapted the concept theories and measure from other discipline although teaching is a distinctive there is a discrepancy in profession, value system and job features. In education context job satisfaction demand to investigate the nature of educational work setting and distinctiveness of teacher themselves to measure the job satisfaction specifically according to education setting. In the current study we applied Lester Paul Teacher job satisfaction Questionnaire (TJSQ) with nine factors, Recognition, Security, Work itself, Responsibility, Working Condition, Advancement, Colleagues, pay, and Supervision.

Supervision factor consists of fourteen items which deals with the two aspects, supervisory behavior and interpersonal relationship with teachers such as, "My immediate supervisor gives me assistance when I need help", "My immediate supervisor provides assistance for improving, instruction," "My immediate supervisor offers suggestions to improve my teaching" are describing the supervisors behavior whereas "My immediate supervisor turns one teacher against another", and "My immediate supervisor makes me feel uncomfortable” explain the interpersonal relation. In this study teacher's satisfaction for supervisory factor is satisfactory. 
Colleague factor consist of ten items which refer to group outcomes and goal interdependence. Items used in factor explain the social aspect of teaching, teaching work groups and social aspect of schools setting. The teachers group work helpful to achieve the common goals. The mutual understanding similarity of attitudes builds the good personnel relationship among the fellow teacher and increases all aspect of social interaction. In our present study the teacher's satisfaction for this factor is moderate. The political interference in schools, the teacher's affiliation with political parties and with teachers associations are the major factor among the teacher which creates non cooperative environment in schools.

The working condition factor contains seven items about teaching situation with context of environmental characteristics such as physical conditions, working environment, school organization and administrative policies. Current research indicates that in AJ\&K, primary teacher are moderate for working condition factor. With context to physical condition, M. Shabbir et al., (2014) investigated the poor physical infrastructure in AJ\&K primary school. According to Pakistan education statistics, (2001112), 175, (41\%) primary school out of 4286 was without buildings, and other facilities like availability electricity, existing furniture, school boundary wall, drinking water latrine were very poor.

Pay factor also contains nine items which explain teaching profession with economic point of view. These items reflect the teacher's attitudes toward wages, teaching income, compensation and survival with teaching income. In our study teacher are satisfied by their pay. After 2002 there was seem to be considerable increase in wages of all employment in AJK. The govt. of AJ\&K introduced the time scale to encourage the school teachers in 2008 which brought a substantial change in wages of schools teachers. But the teachers have less than nine years of service could not benefit by this scheme.

Responsibility factor contains eight items which explain the three components of these factors such as accountability of teacher's own work, student's teacher relations, and contribution in school policies. Responsibility factor, thus, is the need to be accountable for one's own work, to help ones students learn, and chance to play a part in activities relating policy and decision making. The current research refers to teacher satisfied for responsibility factor.

Working itself factor contains nine items related to teacher's daily task, creativeness and independency. The factor of work itself, subsequently, is the teaching job or the tasks related to job. It involves the freedom to use school innovative material, and to utilize skills, abilities to design work as well as experiment. Unfortunately in AJK education infrastructure is poor. Although the teacher are satisfied for this factor but they rarely get chance to 
take part in creative activities because of poor infrastructure and lack of inventive material in public sectors schools.

Advancement factor consists of items related to opportunities of promotion in present teaching position. Advancement or promotion refers to change in current status or position such as primary teacher to junior and then senior. Promotion may be equated in with larger wages and authority. In the current research primary teacher are satisfies with this factor. As mentioned above the time scale is beneficial for upgrading of scale staying in the same status, the teachers who have been remained same status at least nine years get the benefit of better scale without promotion.

Security factor consist of three items related to stability and instability within school organization. This factor refers to tenure, layoff, pension retirement and dismissal. The current research investigated that primary teacher's satisfaction for this factor is moderate.

Recognition factor deals social position, some act of notice, admire, blame, and criticism such as "No one tell me that I am a good teacher", I receive full recognition for my successful teaching. Recognition involves the interest, admiration, status, and regard of supervisors, coworker students and parents. In AJ\&K the primary teacher's satisfaction for this factor is moderate. The primary is the lower rank job in education sector and the teacher get low recognition from the society.

Overall the teacher is slightly satisfied by their jobs. In AJ\&K most of graduates give priority to get job in public sector. There are not prominent jobs for young graduates in private sector. There are no big private industries except of small business and entrepreneurships. So by seeming the unemployment and comparing their jobs with others sector jobs, the primary teachers in AJ\&K look like to be satisfied.

\section{Conclusion}

The Government primary school teachers at Pakistan administrative Kashmir were generally satisfied with four factors of Lester A Paul job satisfaction out of nine factors. The teachers were satisfied with supervision, pay responsibility and advancement factors whereas for other five factors of job satisfaction such as recognition, security, working condition, working itself and colleague, they responded moderate. None of any factor mean value fall in categories of unsatisfied or very satisfied. Overall, the responses indicated that the respondents in this study were satisfied with their job of primary teacher.

\section{Limitations} below:-

Fallowing few limitations of this study which are highlighted as 
$>$ This study is limited to the government primary institutions in Pakistan administrative Kashmir only.

> Sampling technique was applied in this study which has inherent disadvantage of representativeness.

$>$ The results were limited to the data collected by questionnaire method.

$>$ This study does not contain data by, interviews, group, and panel discussion which can be supported to get more solid results.

\section{Recommendation for further study}

Fallowing suggestions are recommended to make the study broad.

$>$ The demographic considerations and personal characteristics may be taken into account in analysis.

$>$ This study is only limited to primary schools, it may be carried out in higher educational institutions, other than primary schools.

$>$ Such kind of studies may be conducted for private institutions.

$>$ A comparative study of job satisfaction of public and private Teachers may be conducted.

\section{References:}

Aliakbari, M. (2013). On the Relationship between Teachers ' Sense of Responsibility and their Job Satisfaction: The Case of Iranian High School Teachers. European Online Journal of Natural and Social Sciences, 2(2), 487-501.

Alimi Baba Gana, A. G. B. and Y. M. K. (2011). An Assessment Of Teacher's Job Satisfaction And Job Performance In Threeselected Secondary Schools Of Borno State, Nigeri. Contenetal J Education Research., 4(1), 2824.

Azhar M.(2011). Job Satisfaction of Secondary School Teachers: A Comparative Analysis of Gender, Urban and Rural Schools. Asian Social Science, 7(8), 203-208. doi:10.5539/ass.v7n8p203

Annual Status of Education (ASER Pakistan) Reports 2010-13.

Bishay, A. (1996). Teacher Motivation and Job Satisfaction: A Study Employing the Experience Sampling Method. J. Undergrad. Sci., 154(Fall 1996), 147-154.

Best, J.W. (1977) Research in Education, Eaglewood cliffs New Jersey: Prentice Hall.

Brayfield, A.H., and Rothe, H.F. (1951). An Index of Job Satisfaction. Journal of Applied Psychology, 35:307-311.

Babbie, R. E. (1986).The Practice Of Social Research. California: Wadsworth Publisher. 
Beer, J., and J. Beer. 1992. "Burnout And Stress, Depression and SelfEsteem of Teachers.” Psychological Reports. 71: 1331-6.

Cranny, C. J., Smith, P. C., \& Stone, E. F. (1992), Job Satisfaction: How People Feel about Their Jobs and How it Affects their Performance. New York: Lexington.

Davis, K., \& Newstrom, J.W. (1985). Human Behavior at Work: Organizational Behavior, Seventh edition. New York: McGraw Hills.

Dinham, S. and Scott, C. (2002), “The International Teacher 2000 Project: An International Study Of Teacher And School Executive Satisfaction, Motivation And Health In Australia, England, USA, Malta And New Zealand", A Paper Presented To The Challenging Futures Conference, University Of New England, Armidale, Australia.

Dimitri Van Maele and, Mieke Van Houtte (2012), “The Role Of Teacher And Faculty Trust In Forming Teachers' Job Satisfaction: Do Years Of Experience Make A Difference"? Teaching And Teacher Education 28 (2012) 879-889

E. C. Papanastasiou and M. Zembylas (2005), "Job Satisfaction Variance Among Public And Private Kindergarten School Teachers In Cyprus", International Journal Of Educational Research, Vol. 43, No. 3, PP. 147-167. Farber, B. A. (1991), Crisis In Education: Stress And Burnout In The American ,Teacher, Jossey-Bass, San Francisco.

Farah Deeba Chughati1 And Uzma Perveen,( 2013) “A Study Of Teachers Workload And Job Satisfaction In Public And Private Schools At Secondary Level In Lahore City Pakistan”,Asian Journal Of Social Sciences \& Humanities, Vol.2 No. 3 P 202-2014

Farida Shaikh, et al., ( 2012) " Critical Analysis Of Job Satisfaction Level Of Female School Teachers At Primary Level In Pakistan” Interdisciplinary Journal Of Contemporary Research In Business, Vol 4, No 8 Pp 660-674 Ghazi, S. R. (2012). Experience And Job Satisfaction Among Bachelor And Master Degree Holder Head Teachers At Elementary Level In Pakistan. Journal Of Educational And Social Research, 2(1), 329-344. Doi:10.5901/Jesr.2012.02.01.329

Government Of Azad Jammu \& Kashmir, 2014. [Online]. Available: Www.Ajk.Gov.Pk/I

Hugh J. Arnold. (1983). Managing Individual And Group Behavior In Organizations. Sydney: Mcgraw-Hill.

Ietje Veldman Et Al.(20013), "Job Satisfaction And Teacher Student Relationships Across The Teaching Career: Four Case Studies” Teaching And Teacher Education 32 (2013) 55-65

Linda Evans, (1997), "Understanding Teacher Morale And Job Satisfaction” Teaching And Teacher Education. Vol. 13, No. 8, Pp. 831-845, 
Lester, P. E. (1987). Development And Factor Analysis Of The Teacher Job Satisfaction Questionnaire, Educational And Psychological Measurement, 47(1), 223-233.

M. Jamal Shah, (2012), "Job Satisfaction And Motivation Of Teachers Of Public Educational Institutions,” International Journal Of Business And Social Science, Vol. 3 No. 8, 271-281

M. Asghar Ali. (2011). A Study Of Job Satisfaction Of Secondary School Teachers. Journal Of Education And Practice, 2(1), 32-37.

Malik (2002), "Kashmir: Ethnic Conflict, International Dispute”, Oxford University Press, USA, PP. 105.

M. Shabbir Et Al., (2014),“A Comparative Study Of Public Versus Private Primary Schools, An Evidence From Azad Kashmir,”Journal Of Education And Practice, Vol.5, No.9, PP 154-1

Mbah, S. E. (2012). Job Satisfaction And Employee S' Turnover Intentions In Total Nigeria Plc . In Lagos State. International Journal Of Humanities And Social Science, 2(14), 275-287.

Milda Astrauskaitè. (2011). Job Satisfaction Survey: A Confirmatory Factor Analysis Based On Secondary School Teachers ' Sample. International Journal Of Business And Management, 6(5), 41-50. Doi:10.5539/Ijbm.V6n5p41

Nadim, M. (2012). Effects Of Motivational Factors On Teachers ' Job Satisfaction: A Study On Public Sector Degree Colleges Of Punjab , Pakistan. The Journal Of Commerce, 4(4), 25-32.

Newstrom J.W. (1986). Human Behavior At Work. New York. Mcgraw-Hill Official Website Of Planning And Development Muzaffarabad - AJK [Online]. Available: Http://Pndajk.Gov.Pk/.

Michalinos Zembylas, Elena Papanastasiou, (2004) "Job Satisfaction Among School Teachers In Cyprus", Journal Of Educational Administration, 42 (3), 357 - 374

Pakistan Education Statistics, 2011, An Analysis Of Educational Indicators Of Pakistan

Papanastasiou, E. C., \& Zembylas, M. (2005). Job Satisfaction Variance Among Public And Private Kindergarten School Teachers In Cyprus. International Journal Of Educational Research, 43(3), 147-167. Doi:10.1016/J.Ijer.2006.06.009

Rajendran, R, D. R., \& Veerasekaran. (2013). “A Study Of Job Satisfaction Of Secondary School Teachers”, International Global Research Analysis, 2(6), 1-2.

Robert W. Lent Et Al.,( 2011), "Predicting The Job And Life Satisfaction Of Italian Teachers: Test Of A Social Cognitive Model”, Journal Of Vocational Behavior 79 (2011) 91-97 
Robert M. Klassen,(2009) “Teaching In The Yukon: Exploring Teachers' Efficacy Beliefs, Stress, And Job Satisfaction In A Remote Setting” International Journal Of Educational Research 48 (2009) 381-394

Shujie Liu , Anthony J. Onwuegbuzie, (2012), "Chinese Teachers' Work Stress And Their Turnover Intention,” International Journal Of Educational Research 53 (2012) 160-170

Spector, A.J. (1956). Expectancies, Fulfillment, And Moral. Journal Of Abnormal And Social Sciences, 52:51-56.

Schonfeld, I. S. 1990. "Psychological Distress In A Sample Of Teachers." The Journal Of Psychology. 124: 321-38.

Troman, G. And Woods, P. (2000), “Careers Under Stress: Teacher Adaptations At A Time Of Intensive Reform.

Van Den Berg, R. (2002), “Teachers' Meanings Regarding Educational Practice”, Review Of Educational Research, Vol. 72, 577-625.

Woods Et Al, (1997), Restructuring Schools; Reconstructing Teachers: Responding To Change In The Primary School, Open University Press, Buckingham

Zembylas, M., \& Papanastasiou, E. (2004). Job Satisfaction Among School Teachers In Cyprus. Journal Of Educational Administration, 42, 357-374 